\title{
Estratégia para produção de revestimento em resíduo de fibra de bananeira promovendo o engajamento dos geradores da matéria-prima
}

\author{
Mariany Costa Carvalho'; \\ Maria Luiza Lopes de Oliveira Santos²;
}

resumo:

A escassez de recursos naturais e os danos ambientais causados pelo descarte desenfreado dos resíduos são problemas que configuram demandas primordiais no Design de Produtos. É necessário compreender os produtos como parte de um conjunto de processos, e não como itens isolados, a fim de desenvolvê-los de maneira sustentável prevendo os impactos existentes em cada etapa do projeto de produção dos mesmos. A observação dos diversos componentes de um sistema, considerando de modo integrado fatores por vezes externos ao campo de atuação principal, destaca-se como a contribuição do Design para a geração e viabilização de soluções. Tal lógica constitui o pensamento sistêmico, abordagem que colabora na construção de alternativas para os problemas do mundo (CARDOSO, 2012). Neste contexto, emerge o conceito de ciclo de vida do produto, cujas fases incluem a pré-produção, produção, distribuição, uso e descarte, com ênfase na importância de se projetar o próprio ciclo de vida do produto (MANZINI; VEZZOLI, 2008). Partindo de tais demandas sustentáveis para o campo do Design e da necessidade de considerar com rigor os materiais e recursos empregados em um produto, investiga-se o problema: como projetar um revestimento decorativo com baixo impacto ambiental a partir da fibra de bananeira, considerando meios de integrar e valorizar a comunidade geradora da matéria-prima? As estratégias para o desenvolvimento de produtos sustentáveis apontam a importância da escolha de recursos e processos cujos efeitos para o meio ambiente sejam reduzidos ao mínimo (MANZINI; VEZZOLI, 2008), o que corrobora na utilização da fibra de bananeira como componente principal do revestimento. Abundante e renovável, a fibra de bananeira é extraída do pseudocaule em um processo benéfico ao próprio crescimento da planta. Atualmente, esta matéria-prima é amplamente utilizada na produção de artesanatos juntamente a outras fibras vegetais de palmeiras, materiais de grande ocorrência no Norte e Nordeste brasileiro, em especial no estado do Maranhão (BORGES, 2011). Como objetivo, pretende-se propor uma estratégia de produção para revestimento de fibra de bananeira de forma ambientalmente responsável na promoção da comunidade geradora da matéria-prima. Para o procedimento metodológico, pretende-se identificar os processos inerentes à geração do resíduo da fibra de bananeira utilizado como matéria-prima, aperfeiçoar os processos para produção de revestimento com fibra de bananeira, bem como analisar o engajamento da comunidade produtora da matéria-prima na perspectiva da responsabilidade ambiental. Para que a pesquisa seja realizada, utilizar-se-á o método Design Science Research (SANTOS, 2018). Este método organiza-se como um ciclo, formado pelas etapas de compreensão do problema, geração de alternativas, desenvolvimento do artefato, avaliações e conclusões (SANTOS, 2018). Espera-se que a pesquisa resulte em meios de reciclar os resíduos provenientes de matérias-primas renováveis e locais, e que, sobretudo, permita construir um método produtivo que inclua de forma colaborativa os geradores do resíduo.

\footnotetext{
${ }^{1}$ http://lattes.cnpq.br/6079268524686595

2 http://lattes.cnpq.br/7052771233872451
} 
palavras-chave:

Design de Produtos; Meio Ambiente; Fibra de Bananeira; Ciclo de Vida do Produto.

Referências:

BORGES, Adélia. Design + Artesanato: o caminho brasileiro. São Paulo: Editora Terceiro Nome, 2011.

CARDOSO, Rafael. Design para um mundo complexo. São Paulo: Cosac Naify, 2012.

MANZINI, E.; VEZZOLI, C. 0 desenvolvimento de produtos sustentáveis. Tradução: Astrid de Carvalho. 1. ed. 2a reimpr. - São Paulo: Editora da Universidade de São Paulo, 2008.

SANTOS, Aguinaldo dos. Seleção do método de pesquisa: guia para pós-graduandos em design e áreas afins. Curitiba: Insight, 2018.

Espaço reservado para organização do congresso. 